\title{
水素用アルミニウム合金の使用環境と 国際標準化に向けた試験方法
}

\author{
伊藤吾朗* \\ * 茨城大学 工学部 機械工学科

\section{Service Environment and Testing Method for Global Standardization of Aluminum Alloys Related to Hydrogen \\ Goroh Itoh* \\ * Ibaraki University, Faculty of Engineering, Department of Mechanical Engineering}

\begin{abstract}
Status quo has been described on the national project for global standardization to define usable aluminum alloys for the use related hydrogen, focusing on the testing method. In the project, test of stress corrosion cracking under humid gas (HG-SCC, Humid Gas Stress Corrosion Cracking) has been proposed as the most suitable testing method. In 6000-series alloys with excess $\mathrm{Si}$, those with and without $\mathrm{Cu}$ have been found to have and not to have resistance to HG-SCC, respectively. Since the knowledge on the stress corrosion cracking in 6000-series alloys is lacking compared to 7000-series alloys, further fundamental study is needed.
\end{abstract}

Key words : hydrogen, aluminum alloy, global standardization, enviornment, testing

\section{1.は じめに}

地球温暖化問題対策の切り札として，水素エネルギー の利用が関心を集めている。このような背景から国立研 究開発法人新エネルギー・産業技術総合開発機構(NEDO) では, 2003 年度から継続して水素社会構築のための基盤 技術開発の目的で大規模な研究プロジェクトを実施して いる ${ }^{1)}$ 。このプロジェクトでは，自動車を現行の内燃機 関車から水素燃料電池車 $(\mathrm{FCV})$ に置き換える計画が大き なウェイトを占めている. 国が揭げる 2050 年における運 輸部門の温室効果ガス排出量 $80 \%$ 削減の目標達成のため に, 2010 年に FCV と水素ステーションの普及に向けたシ ナリオが然料電池実用化推進協議会により策定され ${ }^{2), 3)}$, 2016 年に改訂された ${ }^{4)}$. 2010 年版のシナリオを前倒しに して，2014 年に FCV が市販される一方，VW 社のクリー ンディーゼル車不正問題が明るみになり, 今後このシナ リオ以上に FCV の普及が加速されることが期待される.

ステーションや FCV における水素貯蔵方式には，(1)圧 縮水素, (2) 液体水素, (3) 水素吸蔵・吸着材料の三つが あるが, 現状では圧縮水素を用いる方式が採られている. 圧縮水素容器には, 金属単体の Type- 1 , 金属容器の胴体 を繊維強化樹脂 (FRP) で補強したType-2, 金属ライナー の全体を炭素繊維強化樹脂 (CFRP) で補強した Type-3, 樹脂ライナーの全体を CFRP で補強した Type-4の 4 種 類が使用される ${ }^{5,6)}$. 容器自体のコストは, Type-3 と Type-4 が Type-1の 3〜4 倍といわれ, Type-2 は Type-1 と Type- $3 \cdot 4$ との間と考えてよい. ステーションでは, 国際的にはいずれの種類の容器も使用が認められている. 所定の量の水素を充填する場合の容器質量は, Type-1に

* = 316-8511 日立市中成沢町 4-12-1 (4-12-1, Naka-Narusawa-cho, Hitachi, 316-8511 Japan)
比べて, Type-2 が約 $2 / 3$, Type- $3 \cdot 4$ は約 $1 / 3$ となる. 容器が軽量であるほど壁の厚さも薄くなるため, 同じ水 素充填量に対して，省スペースが実現できる。このため FCVでは省燃費と省スペースの観点から，Type-3 また は Type-4の容器が搭載される. Type-4の容器であって もバルブが取り付けられる口金部分には, 金属が用いら れる。一方，ステーションにおいても，住宅から所定の 離隔距離を取らなければならず，地価の高い都市部に設 置するには，容器を多層に積み上げたり，事務所建屋の 屋上に容器を設置したりする必要が生じてくる．このよ うな場合, Type- 3 や Type -4 容器が用いられることにな る.

Type-3 や Type-4 容器が軽量である反面, 高価である 理由は, 施工費も含めて外層の CFRP が高価であること による. Type-4ではライナーはほとんど強度を担わな いのに対して, Type-3では, 現行の 6061 アルミニウム 合金ライナーにおいて 1 割程度の強度を担っているとい われている。したがってより高強度のアルミニウム合金 を使用し，強度負担比率を高めれば，高価な CFRP の使 用量を削減できる。すなわち今後の FCV 普及の加速に 向けて, より高強度のアルミニウム合金の使用による低 コスト化が期待される ${ }^{5), 6)}$. しかし金属材料は一般に高 強度になると水素脆化を引き起こす恐れがある ${ }^{7)-9)}$ 。 ま た，一方でアルミニウム合金製のスキューバダイビング用 高圧空気容器 (Type-1)において, 過去に事故が多発した こと ${ }^{10), 11)}$ を踏まえ，その後策定された Type-3 も含めたア ルミニウム製天然ガス容器の基準 (JGA 指-NGV07-05)に は，後述する腐食関係の基準が盛り込まれた ${ }^{12)}$ 。本稿で は，これまでの水素関係アルミニウム合金に関する基準 策定に至る経緯を述べ，その後，現在筆者らが取り組ん でいる国際標準化の状況を述べる。 


\section{2. 国内 基 準}

上述のように, NEDO では, 平成 2003 年度から「水素 安全利用等基盤技術開発」を立ち上げ，2004 年に $35 \mathrm{MPa}$ 級の高圧水素容器, 関連部品に関する使用材料の技術基 準 ${ }^{13), 14)}$ を策定した。その中で, Type-3 関係のアルミニ ウム合金として圧縮天然ガス容器において実績のある 6061 合金 $\mathrm{T} 6$ 調質材の使用が認められた。この材料につ いては, $45 \mathrm{MPa}$ の水素中での低ひずみ速度法 (SSRT: Slow Strain Rate Technique)引張試験, 平滑材の疲労試験, 疲労き裂進展試験が行われ, 大気中での特性に比べて, 水素中での特性が劣化しないことが確認された ${ }^{15), 16)}$ 。し かし，それ以前にほかの容器において実績のない合金に ついては全く試験が行われず，使用も認められない状態 となった，また，大きな問題にはなっていないが，条文 の点からも，多少の矛盾がある，その一つに「また，過 剩 $\mathrm{Si}$ のアルミニウム合金であって，耐力が $250 \mathrm{~N} / \mathrm{mm}^{2}$ を超えるものは使用しないこと.」の一文が記されてい ることである。これは, JARI S 以前にあった圧縮天然ガ ス容器の JGA 指-NGV07-05(前述 $)^{12)}$ の影響を受けたと 思われる。過剩 $\mathrm{Si}$ の合金とは, $6000(\mathrm{Al}-\mathrm{Mg}-\mathrm{Si})$ 系合金 において，母相 $\mathrm{Al}$ と平衡する相が $\mathrm{Mg}_{2} \mathrm{Si}$ 相であること に基づいて，合金添加量において $\mathrm{Mg} / \mathrm{Si}$ 原子比が 2 (質 量比で 1.7)より小さい合金を指す ${ }^{17)}$. 主要な 6000 系合 金の組成の Aluminum Association 規格值 ${ }^{18)}$ を Table 1 に 示した。また, $\mathrm{Mg}$ と $\mathrm{Si}$ の規格組成範囲を, $\mathrm{Mg} / \mathrm{Si}$ 原子 比が 2 の直線とともに, Fig. 1 に示した。使用が認められ ている 6061 合金の中でも, $\mathrm{Si}$ が過剩となる組成が生じる

Table 1 Standard composition of major 6000 series aluminum alloys registered in Aluminum Association list ${ }^{18)}$.

\begin{tabular}{|c|c|c|c|c|c|c|c|c|c|c|}
\hline & $\mathrm{Mg}$ & $\mathrm{Si}$ & $\mathrm{Cu}$ & $\mathrm{Mn}$ & $\mathrm{Cr}$ & $\mathrm{Fe}$ & $\mathrm{Zn}$ & $\mathrm{Ti}$ & $\mathrm{V}$ & $\mathrm{Sr}$ \\
\hline 6061 & $0.8-1.2$ & $0.4-0.8$ & $0.15-0.4$ & $<0.15$ & $0.04-0.35$ & $<0.7$ & $<0.25$ & $<0.15$ & - & - \\
\hline 6066 & $0.8-1.4$ & $0.9-1.8$ & $0.7-1.2$ & $0.6-1.1$ & $<0.4$ & $<0.5$ & $<0.25$ & $<0.2$ & - & - \\
\hline 6069 & $1.2-1.6$ & $0.6-1.2$ & $0.55-1.0$ & $<0.05$ & $0.05-0.3$ & $<0.4$ & $<0.05$ & $<0.1$ & $0.1-0.3$ & $<0.05$ \\
\hline 6351 & $0.4-0.8$ & $0.7-1.3$ & $<0.1$ & $0.4-0.8$ & - & $<0.5$ & $<0.2$ & $<0.2$ & - & - \\
\hline 6151 & $0.45-0.8$ & $0.6-1.2$ & $<0.1$ & $0.4-0.8$ & - & $<0.5$ & $<0.25$ & $<0.15$ & - & - \\
\hline 6082 & $0.6-1.2$ & $0.7-1.3$ & $<0.1$ & $0.4-1.0$ & $<0.25$ & $<0.5$ & $<0.2$ & $<0.1$ & - & - \\
\hline
\end{tabular}

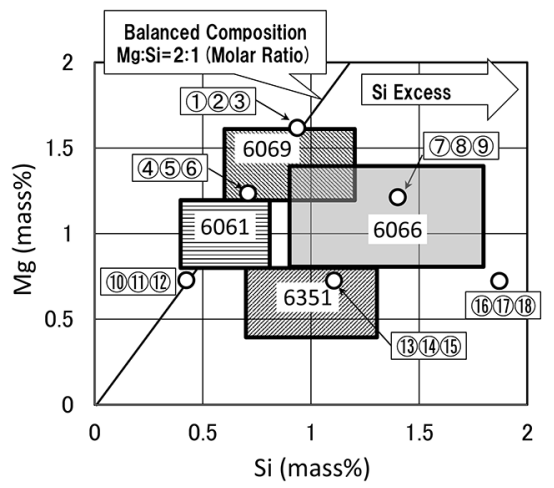

Fig. $1 \mathrm{Mg}$ and $\mathrm{Si}$ compositions of major 6000 series aluminum alloys registered in Aluminum Association list ${ }^{18)}$, together with those of the specimens (number in circle) used in NEDO project ${ }^{19)}$.
ことが分かる. 6061 合金は $\mathrm{T} 6$ 調質で耐力が $250 \mathrm{~N} / \mathrm{mm}^{2}$ 以下となることはほとんどなく（押出管の JIS 規格下限

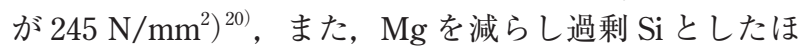
うが，強度を保ちつつ熱間加工性を高めることができる ので，市販されている 6061 合金 T6 材の多くは，過剩 Si 合金で耐力が $250 \mathrm{~N} / \mathrm{mm}^{2}$ を超えることになる.JARI S 001 および 002 では，Fig. 1 において，6351 や 6066 合金 のように規格組成範囲全体が過剩 Si 域にある合金を「過 剩 $\mathrm{Si}$ のアルミニウム合金」と解釈することにし, 6061 合金の多くが使えなくなるという状況は回避されたが, 問題の一文は蛇足となっている.

その後 1 回充填当たりの走行距離をガソリン車並みの $500 \mathrm{~km}$ 程度にするために, 充填圧力を 2 倍の $70 \mathrm{MPa}$ にす る動きが世界的に見られ，国内でもこれに対応できるよ うに, NEDO 事業「水素社会構築共通基盤整備事業/水 素インフラ等に係わる規制再点検及び標準化のための研 究開発 / 水素用アルミ材料の基礎研究」が 2005 2009 年度に行われた。その中で，6061 合金の中で過剩 $\mathrm{Si}$ 側 の端部に位置する組成の合金について，90MPa の水素中 でSSRT引張試験, 平滑材の疲労試験, 疲労き裂進展試 験が行われ，大気中での特性に比べて，水素中での特性 が劣化しないことが確認された ${ }^{21)}$ 。これを受けて 2013 年 5 月に $70 \mathrm{MPa}$ 圧縮水素自動車燃料装置用容器の技術 基準(KHK S 0128) が策定された ${ }^{22)}$ 。この基準において は, JARI S 001 と比較して, 上述の蛇足の一文が削除さ れた程度で，使用可能なアルミニウム合金に関する記述 が, ほとんど踏襲された。すなわち, 使用可能なアルミ ニウム材料は 6061-T6のみのままである.

\section{3. 国際標準化}

自動車は多量に輸出入されるため, FCV および関連部 品も今後当然国際的な移動が頻繁に起こると予想され る. それに備えて使用可能な材料についても, 国際標準 が策定され，国内標準がそれに整合していなければなら ない。現在，国連欧州経済委員会に設けられた自動車基 準調和世界フォーラム (UN/ECE/WP29)の場を活用し, HFCV-GTR (水素 - 燃料電池自動車の世界統一技術基準) が策定されようとしている。この GTR(Global Technical Regulation)では，これまでの国内基準で設計要件を課し てきたのに対して，性能要件を課そうとしていることが 大きく異なる．すなわちアルミニウム合金についてみる と，これまでの JARI S や KHK S で 6061-T6 と材料種を 指定したのに対して，評価法を定めて，それに合格した 材料は材料種によらず使用が認められるようになる。そ うなると今度は評価(試験)法を定めることが重要とな る。また一方で容器を製造しようとする度に, 評価を受 けなければならないのは, 煩雑であるので, 一度合格し た材料は無試験で使用できるようにしたいところであ る.

FCV が話題になる以前に，圧縮天然ガスに関わる既述 の基準 JGA 指-NGV07-05 では，6061-T6，6151-T6(ただ し 6151-T6については耐力 250MPa 以下に限る) は評価試 験なしで使用が認められ，それ以外のアルミニウム合金 については，粒界腐食(IGC: Intergranular Corrosion)試 験, 応力腐食割れ (SCC: Stress Corrosion Cracking) 試験, 
長期負荷割れ試験(SLC: Sustained Load Cracking)のいず れにも合格することが使用の条件となっている，すなわ ち，無試験で使用できる材料を規定する一方で，それ以 外の材料でも評価試験に合格すれば使用できるという道 を残している。この評価試験は，おおむね国際規格の評 価試験法 ISO-7866 ${ }^{23)}$ Annex A, B に準拠している. 上述 のように今後策定される国際標準も，大枠としてはこの ように 2 段構えの仕組みになろう。なお， 6061 とともに 耐力の制限があるものの無試験で使用可能となっている 6151 合金は Table 1 から分かるように，ほほ 6351 合金 と同じく，規格組成範囲全体が過剩 Si 域にある合金で ある.JARI S において,「また, 過剩 $\mathrm{Si}$ のアルミニウム 合金であって，耐力が $250 \mathrm{~N} / \mathrm{mm}^{2}$ を超えるものは使用し ないこと.」の一文が残ったのは, JGA 指-NGV07-05 の 6151 に関する条件に影響されたものと推察される.

\section{4. アルミニウム材料評価試験法の検討}

このような状況下において, NEDOの事業として, 「水素利用技術研究開発事業/燃料電池自動車及び水素 供給インフラの国内規制適正化，国際基準調和・国際標 準化に関する研究開発 /自動車用圧縮水素容器の基準整 備・国際基準調和に関する研究開発」事業が 2013 年度 から開始された。自動車用圧縮水素容器およびこれに関 連するアルミニウム材料の基準整備・国際基準調和のた めの審議に必要なデー夕取得が主目的である.

アルミニウム材料使用の基準を策定するに当たって， まずアルミニウム材料が使用される環境を, Fig. 2 に示 すように, 水素に曝されるが大気には曝されない内部環 境と, 逆に大気に曝されるが水素に曝されない外部環境 に分ける必要があるとの結論に達した ${ }^{24)}$ 。外部環境は, 特に水素容器に限られた環境ではない. 使用環境として は，通常の自動車に使用される足回り部品のように，融 雪剤などの過酷な環境になるが，これに耐えるアルミニ ウム材料の選定については, 自動車製造企業が独自の基 準を設け，重大な事故例は報告されていない。したがっ て今回新たに策定しなければならないのは，内部環境に 曝される材料の基準(評価法)である.

アルミニウム合金が容器内部に使用可能となるプロセ スについては, Fig. 3 の流れを提案している.この中の 水素適合性については, 前述の KHK S 0128 策定時のよ うに $70 \mathrm{MPa}$ の高压水素であるので，水素適合性を評価 すればよいことになり，既述のように， $90 \mathrm{MPa}$ の水素中 でSSRT引張試験, 平滑材の疲労試験, 疲労き裂進展試

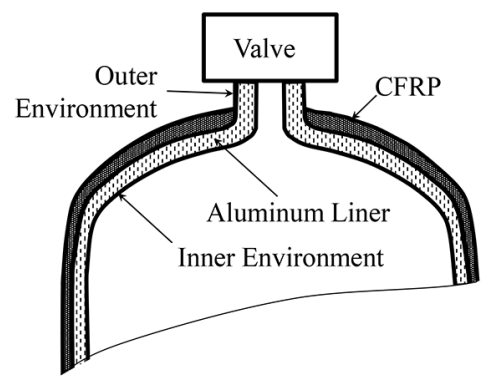

Fig. 2 Environment during the use of type-3 container.

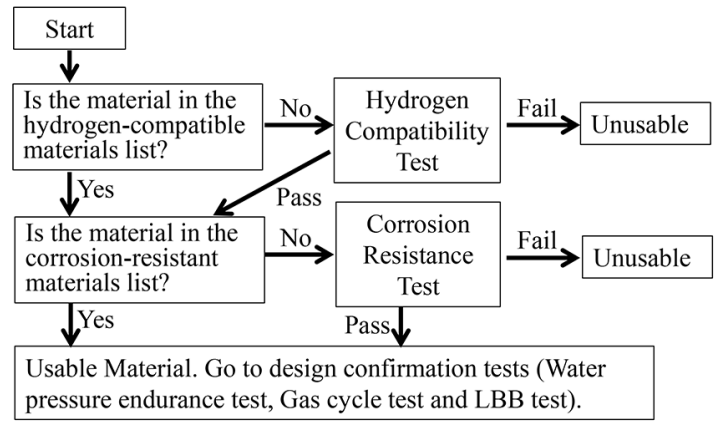

Fig. 3 Procedures for aluminum alloys to be a usable material for high pressure hydrogen container.

験を行い, 大気中とそん色ない特性が得られれば使用可 能になる．これまでのアルミニウム合金に関するデータ では，大気中に比べて高圧水素中で力学特性が劣るとい う結果は見られていない 15),16),21,25)-28) ことから，実用ア ルミニウム合金はこの試験を経ずに(すべて適合性リス トに載る)，次の耐食性の評価に進むことができると考 えている.

しかしここで注意しなければならないのは水素中の不 純物水分である. 試験環境中の水蒸気は金属アルミニウ ムと式(1)の反応を起こし, 熱力学的計算ではそのとき に生じる水素ガスのフガシティが $10^{53} \mathrm{~Pa}$ 以上と桁外れに 高くなり（相対湿度 $87 \%$, 温度 $25^{\circ} \mathrm{C}$ において $X=3$ の水 和酸化物バイエライトが生じる場合 $)^{29)}$, 生じた水素ガ スの一部が原子状水素として材料内に侵入し, 水素脆化 を引き起こす可能性があると考えられている.

$$
2 \mathrm{Al}(\mathrm{s})+(3+X) \mathrm{H}_{2} \mathrm{O} \rightarrow \mathrm{Al}_{2} \mathrm{O}_{3} \cdot X\left(\mathrm{H}_{2} \mathrm{O}\right)(\mathrm{s})+3 \mathrm{H}_{2}(\mathrm{~g})
$$

一般にアルミニウムの酸化皮膜は保護性が高く, 式 (1) の反応が生じても，その部分が直ちに保護性皮膜に覆わ れ反応は持続しない. しかし低ひずみ速度で引張試験す れば，絶えず金属新生面を露出させることができる．こ のことを利用して Fig. $4^{30)}$ に示すように，湿潤大気中で の低ひずみ速度試験法が耐水素脆化特性を評価する手法 として提案されている. Fig. $5^{27)} に ， 6061$ および7075ア ルミニウム合金のいずれも $\mathrm{T} 6$ 材について，大気圧下で の乾燥窒素および湿潤空気中 (相対湿度 $90 \%$ ), $85 \mathrm{MPa}$ の高圧下での水素および窒素中で, 引張試験したときの

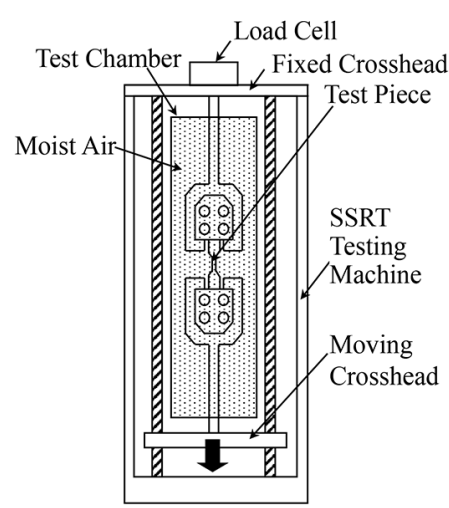

Fig. 4 Schematic for the SSRT (Slow Strain Rate Technique) tensile test ${ }^{30)}$. 

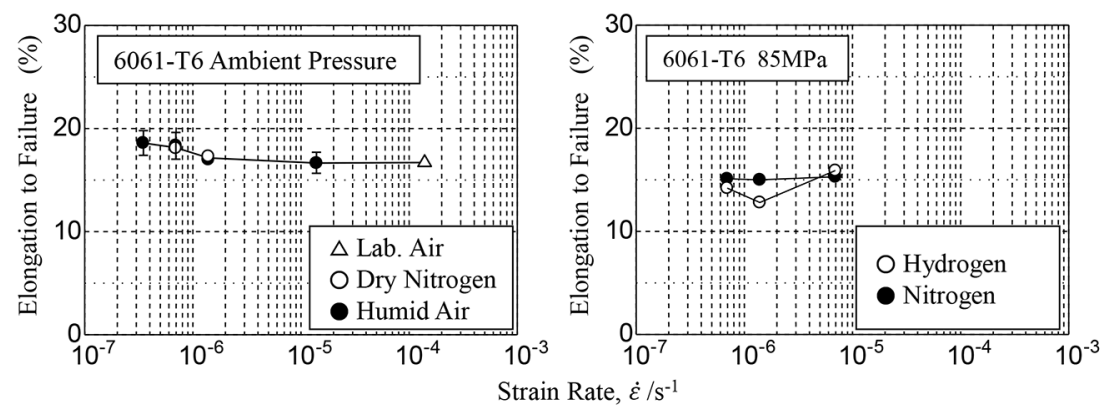

ひずみ速度での試験は，実施は 困難ではないが，例えばひずみ 速度 $10^{-6} \mathrm{~s}^{-1}$ で湿潤環境下での破 断伸びが $10 \%$ でも，破断まで の時間は $10^{5} \mathrm{~s}=27.8 \mathrm{~h}$ であり, 現在 FCV の水素容器に求めら れている 15 年無検査という条 件からはほど遠い.ひずみ速度 の低下とともに脆化が顕著とな るのは, 式(1)の反応により発
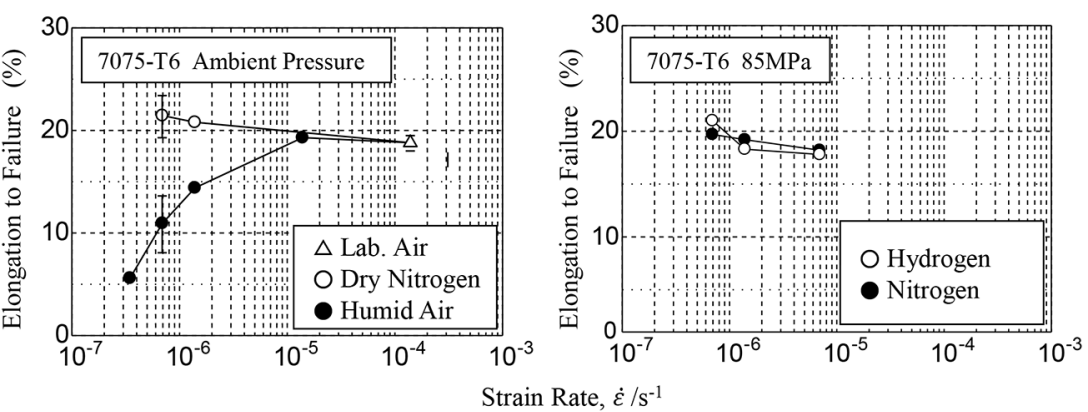
生した水素がき裂前方に拡散す るのに時間を要するためと考え られるが, 有限の平行部長さを 持つ試験片で低ひずみ速度で試 験しても，き裂が発生するとそ こに変形が集中する(変形領域 が著しく短くなる)ので，ひずみ 速度は急増し, 低ひずみ速度の 条件が崩れてしまう. Fig. $7^{25)}$ は, Fig. 5 の湿潤大気環境での 試験を, 試験片板厚を 5 倍, 平 行部幅を 2.4 倍にした試験片を 用いて行った結果である. 破断 伸びで測定した限りひずみ速度

破断伸びとひずみ速度の関係を示した７075-T6 材では， 湿潤空気中で試験した場合に，ひずみ速度が遅くなるほ

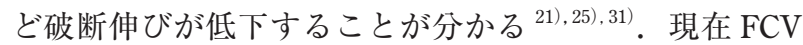
に使用が認められている水素ガス中の不純物水分の許容 量は $5 \mathrm{ppm}$ であるが, Fig. 6 に示すように, $5 \mathrm{ppm}$ の水分

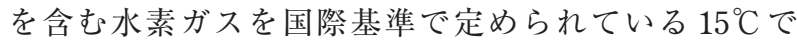
$70 \mathrm{MPa}$ に充填すると， $-7^{\circ} \mathrm{C}$ で相対湿度が $90 \%$ に達する。 ベース環境が大気でなく水素であっても，合金によって は, 乾燥環境で進展しないき裂が湿潤環境にすると進展 するとの報告がある ${ }^{32)}$. したがってアルミニウム合金の 場合, 水素に曝され大気と遮断される内面において, 水 素中の水分による脆化を懸念する必要がある. 高圧水素 ガス中で湿度を調整する試験は，実施困難であり， Fig. 5 のように大気中でも高湿度とすることにより脆化が見ら れることから，湿潤大気環境での試験が評価環境として 妥当と考えられる.

一方, 荷重の負荷方法については, Fig. 5 のような低

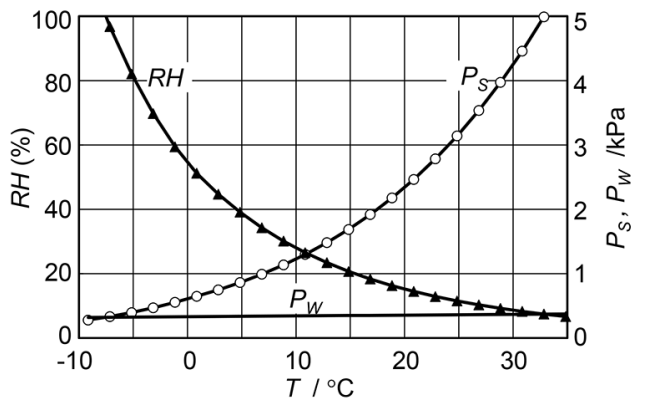

Fig. 6 Temperature dependence of saturate water vapor pressure, $\mathrm{P}_{\mathrm{S}}$, partial water vapor pressure in hydrogen gas of $70 \mathrm{MPa}$ with impurity hydrogen of $5 \mathrm{ppm}, \mathrm{P}_{\mathrm{W}}$, and relative humidity, $\mathrm{RH}$.
を遅くしても脆化が現れないことが注目される．破面観 察の結果，5mm 厚の試験材の破面にも，1mm 厚材と同 様に水素脆性を裏付ける粒界破面が見られたが, 試験片 断面積が大きいことにより，破面全体に対する粒界破面 の割合が著しく小さくなった ${ }^{25)}$ 。この結果は, 上述の推 測どおり，き裂がある程度進展すると，変形がその先端 に集中するため，局所的なひずみ速度が急増し，水素の 供給が追いつかなくなることによると考えられる。この ようなことから，低ひずみ速度法による負荷は，湿潤環 境下で長期間曝されるアルミニウム合金の安全性を評価 するには適当でないと考えられる。一般に耐応力腐食割 れ性の試験として用いられる平滑試験片に対して一定荷 重を負荷する方法も, き裂発生によるひずみ速度の急増 を招く点では同様である.

そこで評価法の候補として挙げられたのが，前述の ISO 7866 Annex B に規定されている予き裂を与えた試験 片における引張荷重負荷中のき裂進展量で評価する長期 負荷割れ方式である。この方式では，疲労予き裂を導入 しておき, その先端に所定の応力拡大係数值 $\left(K_{I A p p}\right)$ を与 えるものであり，平滑材のようにき裂の発生により局所

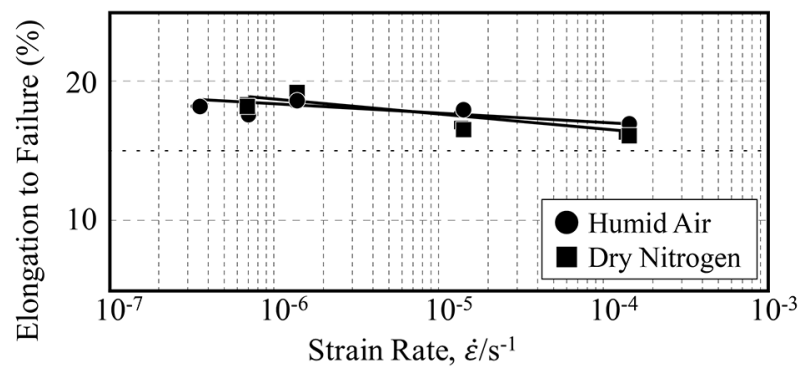

Fig. 7 Relationship between elongation to failure and strain rate of 7075-T6 specimen with $5 \mathrm{~mm}$ thickness. 
的ひずみ速度が急増することがない。またすでに ISO 7866 Annex B や JGA 指-NGV07-05 の別表第 3 として規 定されている方式なので, GTRに採用される可能性が高 いと判断し，この方式を NEDO 事業では, HG-SCC 試 験として, GTRに提案しょうとしている，なお，従来の 長期負荷割れでは，長期間保持の環境について規定がな い.これは, 長期負荷割れの機構が解明されないまま, かつ不純物の $\mathrm{Pb}$ や $\mathrm{Bi}$ に原因があると考えられた ${ }^{33}$ こと にも関係があるように思われる。

合格·不合格の判定について，長期負荷割れ試験では, 90d の負荷中に $0.16 \mathrm{~mm}$ 以上のき裂進展がなければ合格 とすることにしているが, 負荷中のき裂進展量の測定に は, 負荷終了後に再び疲労負荷を与えた後, 急速破断さ せて二つの疲労破面に挟まれた領域を長期負荷割れと判 断することになっているが，現在行っている NEDO 事 業での試験結果では，疲労き裂と長期負荷き裂の区別が 困難な場合が比較的高い頻度で表れている。そこで，負 荷終了後については, 破断が予測される面と表面との交 線に, 液体ガリウムを塗布して, 液体金属脆性を利用し て極めて低い荷重で塑性変形が関与しない粒界破壊を起 こさせ ${ }^{34)} て$, 観察する方法を採用しつつある.

\section{HG-SCC の機構}

NEDO 事業とは別に，すでに過剩 Si 型の 6351 合金と 6066 合金について湿潤環境中で長期負荷割れ試験を行っ た結果が報告されている ${ }^{35)}$ ，その結果によると，6351 合金では長期負荷中にき裂が著しく進展し，前述の判定 基準によると不合格となるのに対して，6066 合金ではき 裂がまったく進展しない。報告には $0.2 \%$ 耐力は明記さ れていないが, 負荷している $K_{I A p p}$ から, 6351 合金が $311 \mathrm{MPa} ， 6066$ 合金が $339 \mathrm{MPa}$ と見積もられ，6066 合金 が特に耐力が低いわけでない。この差の原因については 特に論じられていないが, Table 1 の規格組成から, 強度 向上のために添加される $\mathrm{Cu}^{36)}$ の量が大きく異なることに あると推察される。すなわち 6351 合金では， $\mathrm{Cu}$ は $0.1 \%$ 以下に抑えなければならないが, 6066 合金では 0.7〜 $1.2 \%$ 添加しなければならない。

これに関連して，ある合金の試験材が評価試験で合格 になったとしても，必ずしもその合金と同じ規格番号の 合金がすべて使用可能になるとは限らない. Table 1 や Fig. 1 で分かるように，規格合金には許容組成範囲があ る.したがってその中の 1 組成の合金の試験材で合格に なったとしても，その範囲内のほかの組成 (さらには熱 処理条件)の材料が合格するとは限らない. 仮にある元 素の組成 (含有量) と耐 HG-SCC 性など評価特性が単調 な関係にあるとしても，1元素について範囲の両端の $(2$ 通りの)組成を評価しなければならない. Table 1 に示す ようにAluminum Associationの規格に登録されている合 金は,ごくまれにしか添加されないV V Srを除いても 8 種類の元素について規定されている. 1 元素について 規格の両端の 2 組成について試験しなければならないと すると, 一つの規格合金の使用可能性を決定するには, 組み合わせとして $2^{8}=256$ 通りの組成の試験材を製造 して，合否を判定しなければならないことになる。これ を回避し, より少ない試験材で済ますためには, 各元素
が耐 HG-SCC 性に有害なのか，影響がないのか，有益 なのかを明らかにしなければならない。一般に応力腐食 割れは，高強度になるほどすなわち合金元素量が多くな

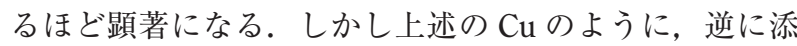
加したほうが湿潤環境下での耐長期負荷割れ性を改善す る元素が存在するということは，ある規格合金を使用可 能とする基準作成において，材料評価を複雑にする。そ こでNEDO 事業では，まず 6000 系合金の基本であり， 強度に直結する $\mathrm{Mg}, \mathrm{Si}, \mathrm{Cu}$ の 3 元素について, Fig. 1 に丸数字で記した 18 種類の組成の合金を調製し，その 耐 HG-SCC 性を評価しつつある(同じ $\mathrm{Mg}, \mathrm{Si}$ の組成に三 つの丸数字があるのは, $\mathrm{Cu}$ の添加量が， $0,0.3,1.0 \%$ と 異なることを意味する).

学術的には, 前述の 6351 合金と 6066 合金との違い(添 加 $\mathrm{Cu}$ の影響) が興味深い。粒界近傍では，粒界上に $\mathrm{Cu}$ を含む化合物相が析出するため, それに隣接する無析出 帯では母相の $\mathrm{Cu}$ 濃度が低くなり, 粒界から遠ざかるに つれて, $\mathrm{Cu}$ 濃度は高くなる. $\mathrm{Cu}$ を固溶した母相や $\mathrm{Cu}$ を含む析出物は電気化学的に貴なため, 腐食環境下では 隣接するアルミニウム母相が溶出することが知られてい る ${ }^{37)}$ が, 湿潤ガス環境下では溶液がないので溶出は起こ らない. 破面についても，7000 系合金の水素脆化の破面 は塑性変形の痕跡がほとんどない破面 ${ }^{25)}$ となるのに対し て, 6351 合金の HG-SCC 破面は微細ディンプルを伴う (粒界に沿った無析出帯で塑性変形が起こる) 粒界破面に なると報告されている ${ }^{35)}$. HG-SCCではないが, Aucote と Evans は, 過剩 Si 合金で低延性・低勒性になること, その原因として粒界破面について EDX 分析を行った結 果から $\mathrm{Si}$ 相の粒界析出が低勒性の原因としている ${ }^{38)}$ が, $\mathrm{Si}$ 相の析出は $\mathrm{T} 6$ 程度の時効状態では生じないとする報 告 ${ }^{39), 40)}$ もある。一方, 松田らは, 平滑材の引張試験に おいて Si 過剩合金では粒界に沿った無析出帯に変形が 集中するのに対して，それに $\mathrm{Cu}$ を添加した合金では無 析出帯の幅が狭くなり, 变形が粒内全体に分散し, 延性 が向上するとしている ${ }^{41)}$.このように静的な機械的特性 に関する研究結果はいくつか報告されているが，6000 系 合金では, 7000 系合金に比べて応力腐食割れや水素脆化 に鈍感であるため，これまで HG-SCC に及ぼす組成の影 響や，HG-SCC 機構について詳しく調べられてこなかっ た. 過剩 $\mathrm{Si}$ の影響と, $\mathrm{Cu}$ 添加の影響については, 今後 引き続き調査しなければならない。

\section{6. まとめと今後の課題}

これまでの水素関係アルミニウム合金(主に 6000 系ア ルミニウム合金)に関する基準策定に至る経緯を踏まえ, 現在筆者らが取り組んでいる国際標準化, 使用可能なア ルミニウム材料の評価試験として, 湿潤大気中での応力 腐食割れ試験(耐 HG-SCC 性試験)が適当であること, 過 剩シリコン型合金でも $\mathrm{Cu}$ 無添加の合金では HG-SCC に 敏感であるが, $\mathrm{Cu}$ が添加されている合金では, HG-SCC

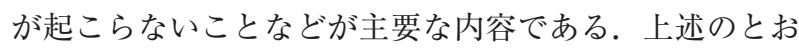
り，6000 系合金では，応力腐食割れに関する知見が不足 しており，本稿を機に腐食防食分野の専門家諸兄から助 言をいただければ幸いである。 


\section{謝辞}

本稿の内容は，おおむね NEDO 事業「水素利用技術 研究開発事業／燃料電池自動車及び水素供給インフラの 国内規制適正化，国際基準調和・国際標準化に関する研 究開発 /自動車用圧縮水素容器の基準整備・国際基準調 和に関する研究開発」で得られた成果に基づいているこ とを記し，関係各位に謝意を表します。

\section{参 考 文 献}

1) 30 Years of NEDO, NEDO, p.88 (2010).

2) Scenario for the Diffusion of Fuel Cell Vehicles and Hydrogen Infrastructures 2010, 〈http://www.fccj.jp/ pdf/22_csj.pdf $>$.

3) A. Sakakida, Materials for Storage and Safety of Hydrogen, Science \& Technology, p.227 (2010).

4) Scenario for the Diffusion of Fuel Cell Vehicles and Hydrogen Infrastructures 2010, 〈http://www.fccj.jp/pdf/ fccj_pamphlet.pdf $\rangle$.

5) T. Yamamoto and Y. Sakaguchi, Aluminium, 14, p.109 (2007).

6) Y. Sakaguchi, Materials for Storage and Safety of Hydrogen, Science \& Technology, p.245 (2010).

7) Introduction to Materials Ecology (Jpn.), JSCE, Maruzen, p.45 (1993).

8) M. Nagumo, Fundamentals of Hydrogen Embrittlement, Uchida Rokakuho Publishing, p.185 (2008)

9) Y. Murakami, S. Matsuoka, Y. Kondo and S. Nishimura, Mechanism of Hydrogen Embrittlement and Guide for Fatigue Design, Yokendo, p.1 (2012).

10) G.S. Bhuyan and D.H. Carter, Intern. J. Pressure Vessels Piping, 60, p.183(1994).

11) Report of Investigation on Aluminum Alloy Gas Containers for Scuba Diving, Committee of Investigation on Aluminum Alloy Gas Containers for Scuba Diving, p.1 (2001).

12) Technical Standard for Containers of the Combustion Device for Compressed Natural Gas Vehicles, 〈search.e-gov.go.jp/ servlet/PcmFileDownload?seqNo $=0000010013\rangle$.

13) Technical Standard for Containers of the Fuel Device for Compressed Hydrogen Vehicles (JARI S 001), Japan Automobile Research Association (2004).

14) Technical Standard for Accessories of the Fuel Device for Compressed Hydrogen Vehicles (JARI S 002), Japan Automobile Research Association (2004).

15) S. Omiya and H. Fujii, CAMP-ISIJ, 18[3] p.596(2005).

16) S. Omiya and H. Fujii, CAMP-ISIJ, 18[3] p.597 (2005).

17） K. Ohori, J. Jpn. Inst. Light Met., 38, p.748(1988).

18) Aluminium Handbook, JAA, p.229 (2001).

19) Research and Development Project for the Usage Technology of Hydrogen/Research and Development on Optimization of Domestic Regulation, International Standard Harmony, and International Standardization/ Research and Development on Standard Maintenance and International Standard Harmony for Compressed Hydrogen Gas Containers for
Automobiles (FY2013-FY2017) FY2015 Annual Report, NEDO, p.9 (2016).

20) Aluminium Handbook, JAA, p.295 (2001).

21) G. Itoh, Materials for Storage and Safety of Hydrogen, Science \& Technology, p.234 (2010).

22) Technical Standard for Containers of the Fuel Device for Compressed 70MPa Hydrogen Vehicles (KHK S 0128), The high Pressure Gas Safety Institute of Japan (2010).

23) ISO 7866, Gas cylinders--Refillable seamless aluminumalloy gas cylinders - Design, construction and testing, 2nd Ed. (2012).

24) Preprint in the Field of Fuel Cell and Hydrogen of the Meeting of Reports on New Energy in Fiscal Year 2015, NEDO, p.230 (2015).

25) Report on "Establishment of codes and standards for hydrogen economy society - Fuel cell vehicles, Distributed fuel cell system installed into houses, Hydrogen infrastructures - -Basic Research on Aluminum-Based Materials for Hydrogen" in Fiscal Year from 2005 to 2009, NEDO, p.264, 491 (2010).

26) M. Yabumoto, K. Yokogawa, T. Ogata, H. Nakagawa, H. Eguchi, H. Fujii, S. Okaguchi, K. Ishio, M. Hayashi and M. Saito, J. High Press. Inst. Jpn., 38, p.319(2000).

27) Guidebook for Effective Use of Hydrogen, NEDO, p.81 (2008).

28) Safety Standard for Hydrogen and Hydrogen Systems, NASA (2005).

29) R. E. Ricker and D. J. Duquette, Metall. Trans. A, 19A, p.1775(1988).

30） G. Itoh, S. Osaki, K. Ito, Q. Cui, K. Koyama, T. Tsuchida, M. Nakai and T. Hashimoto, Preprint in the Meeting of Reports on the Technological Development in Fuel Cell and Hydrogen/ Development in Basic Technology in the Safety Use of Hydrogen/ in Fiscal Year 2003, NEDO, p.33 (2004).

31) S. Osaki, J. Ikeda, K. Kinoshita and Y. Sasaki, J. Jpn. Inst. Light Met., 56, p.721(2006).

32) M. O. Speidel, The theory of stress corrosion cracking in alloys, NATO, p.289 (1971).

33) J. J. Lewandowski, Y. S. Kim and N. J. H. Holroyd, Metall. Trans. A, 23A, p.1679 (1992).

34） T. Mae and S. Hori, J. Jpn. Inst. Light Met., 37, 141(1987).

35) T. Kanezaki, S. Mano, K. Miyagawa, N. Hayashi and T. Ogawa, Honda R\&D Technical Review, 26, p.139(2014).

36) H. Suzuki, M. Kanno, Y. Shiraishi and K. Hanawa, J. Jpn. Inst. Light Met., 29, p.575(1979).

37) Y. Kojima, Furukawa-Sky Review, 2, p.62 (2006).

38) J. Aucote and D. W. Evans, Metal Sci., 12, p.57(1978).

39) M. Kanno, H. Suzuki and Y. Shiraishi, J. Jpn. Inst. Light Met., 28, p.553 (1978).

40) Y. Uetani, M. Isurugi, K. Matsuda, S. Tada and S. Ikeno, J. Jpn. Inst. Light Met., 42, p.578(1992).

41) K. Matsuda, Y. Myotoku, K. Kido, Y. Uetani and S. Ikeno, J. Jpn. Inst. Light Met., 53, p.2(2003).

$(2016$ 年 5 月 12 日受理 $)$

\section{要旨}

水素関係用途の使用可能なアルミニウム合金を定義するための国際標準化を目的とした国家プロジェク トについて, 試験方法に焦点を当てて述べた。このプロジェクトでは, 湿潤ガス環境下での応力腐食割れ (HG-SCC, 湿潤ガス応力腐食割れ)試験が最も適切な試験として提案されている。過剩シリコン $(\mathrm{Si})$ 型の 6000 系合金では，Cu を含む合金では耐 HG-SCC 性を有するのに対して，Cu 含まない合金では，耐 HG-SCC 性 を持たないことが分かった。 6000 系合金の応力腐食割れに関する知見は，7000 系合金に比べて不足して いるため, 今後更なる研究が必要である.

キーワード＼cjkstart水素, アルミニウム合金, 国際標準化, 環境, 試験 